\title{
As armas dos fracos: estratégias, táticas e repercussões identitárias na dinâmica do acesso à saúde na fronteira Brasil/Paraguai
}

The weapons of the weak: identity strategies, tactics and impact on the dynamics of health access in the Brazil/Paraguay border

Valdir Aragão Nascimento*

* Universidade Federal de Mato Grosso do Sul - Campo Grande, MS, Brasil Doutorando em Saúde e Desenvolvimento na Região Centro-Oeste (bolsista Capes) 33valdir@gmail.com

Sônia Maria Oliveira de Andrade ${ }^{* *}$

** Universidade Federal de Mato Grosso do Sul - Campo Grande, MS, Brasil soniaufms@gmail.com 


\begin{abstract}
Resumo
O presente artigo objetiva expor e discutir algumas táticas e estratégias adotadas por paraguaios indocumentados para ter acesso à saúde por meio do SUS no Brasil. A pesquisa de campo realizou-se especificamente entre a cidade paraguaia de Pedro Juan Caballero e a cidade brasileira de Ponta Porã. Outro objetivo é discutir as relações socioculturais de caráter identitário que essas táticas e estratégias engendram e oportunizam na faixa de fronteira em questão. No tocante às táticas e estratégias, elencamos as concepções teóricas de Michel de Certeau a respeito dessas categorias. Fredrik Barth e seus conceitos atinentes aos grupos étnicos dão a tônica de nossa análise acerca das diversas, e por vezes divergentes, identidades étnicas oriundas das inter-relações estabelecidas na dinâmica que propicia a existência de táticas e estratégias - no tocante ao acesso à saúde - na fronteira do Brasil com o Paraguai.
\end{abstract}

Palavras-chave: estratégias e táticas; identidades étnicas; fronteira Brasil/Paraguai; dinâmicas de saúde na fronteira

\begin{abstract}
This article aims to expose and discuss some of the tactics and strategies adopted by undocumented Paraguayans to access health through SUS in Brazil. Field research was carried out specifically between the Paraguayan city of Pedro Juan Caballero and the Brazilian city of Ponta Porã. Another objective is to discuss the sociocultural relations of identity that these tactics and strategies engender and opportunize in the border area in question. With regard to tactics and strategies, we list Michel de Certeau's theoretical conceptions of these categories. Fredrik Barth and his concepts concerning ethnic groups emphasize our analysis of the diverse and sometimes divergent ethnic identities arising from the interrelationships established in the dynamics that give rise to tactics and strategies in terms of access to health, On the border of Brazil and Paraguay.
\end{abstract}

Keywords: strategies and tactics; ethnic identities; Brazil/Paraguay border; dynamics of health at the border 


\section{Introdução}

A fronteira guarda em si intrincados desdobramentos e ocorrência de fenômenos socioculturais, o que deve ser considerado quando da elaboração de projetos e políticas públicas que tenham o espaço de fronteira como objeto. Para além de questões meramente geográficas, esses espaços se caracterizam pelas diversas e multifacetadas relações e inter-relações que sua condição de fronteira enseja. Aqui, questões como educação, soberania, identidade e saúde assumem contornos sui generis, dada a natureza de sua existência.

O acesso à saúde nas fronteiras do Brasil com os países que com ele se limitam geograficamente tem se constituído um sério problema às autoridades brasileiras. Pensados para atender aos seus nacionais, os recursos alocados não dão conta de atender a contento àqueles estrangeiros que porventura busquem atendimento no país. Contudo, em que pesem as limitações de todos os tipos, o atendimento é realizado, principalmente quando emergenciais, dado que a omissão de socorro é tipificada no artigo 145 do Código Penal como crime, pelo qual o profissional que nele incorrer deve ser responsabilizado, sendo possíveis ainda as penas de prisão e multa (Brasil, 1940).

Aos estrangeiros residentes no Brasil, o acesso é garantido pela lei $\mathrm{n}^{\circ}$ 6.815/1980, conhecida também como Estatuto do Estrangeiro (Brasil, 1980). Esse dispositivo legal regulamenta a situação jurídica de indivíduos de outras nacionalidades em solo brasileiro, segundo seu artigo 95: "O estrangeiro residente no Brasil goza de todos os direitos reconhecidos aos brasileiros, nos termos da Constituição e das leis."

Para aqueles indocumentados, o acesso é oportunizado por meio de algumas condições, tais como o agravamento dos casos de saúde até um nível crítico, o que obriga os profissionais a atenderem o paciente; a obtenção de documentos através de meios não legítimos; e/ou das redes de solidariedade estabelecidas entre brasileiros e paraguaios no contexto de fronteira. Uma tática eficiente para se ter acesso aos serviços é o aluguel de endereços, que consiste na obtenção de boletos de água e luz, sem fotos, para comprovar residência junto aos postos de atendimento (Giovanella et al., 2007).

Esses expedientes, bem como o atendimento em si aos estrangeiros, reverberam no seio da sociedade local, despertando sentimentos às vezes negativos - ou fortalecendo os já existentes - por parte dos brasileiros em relação aos 
paraguaios e vice-versa. A situação é paradoxal, posto que se de um lado existem brasileiros que emprestam ou alugam endereços a paraguaios, de outro existem aqueles que condenam não só a prática em si, mas a própria utilização dos serviços pelos paraguaios (Preuss, 2011).

Nas cidades fronteiriças de Pedro Juan Caballero (Paraguai) e Ponta Porã (MS) essa problemática do acesso à saúde é também uma constante, levando brasileiros e paraguaios em situação de vulnerabilidade a elaborar estratégias para poder contornar e, assim, suprimir os obstáculos que se lhes apresentam no tocante ao acesso aos serviços de saúde na faixa de fronteira em questão.

Nessa querela em que o acesso à saúde é o mote, vêm à baila questões de todo tipo, inclusive identitárias. Podem ser reforçadas as acusações mútuas entre os indivíduos dos dois países; exacerbam-se os sinais diacríticos e os signos identitários e as identidades se tornam fluídas e situacionais, adequando-se à realidade das interações tanto institucionais quanto pessoais.

As questões a respeito das estratégias e táticas adotadas no processo de obtenção de serviços de saúde na fronteira Brasil/Paraguai, especificamente nas cidades de Pedro Juan Caballero e Ponta Porã, são emblemáticas no que tange às manifestações identitárias que têm lugar naquela região. As cidades mencionadas têm uma particularidade em relação à sua condição de fronteira: são consideradas cidades-gêmeas, caracterizadas pela maior proximidade de seus limites e pelas diversas e diversificadas relações socioculturais que tal proximidade enseja.

Desvelar a dinâmica que permeia esses expedientes é fundamental para se entender não só como realmente funciona o acesso à saúde naquela fronteira em particular, mas como se percebem e se representam tanto brasileiros quanto paraguaios nessa interação.

\section{"Isso aí vai virar livro?" Breves considerações sobre o trabalho de campo e suas dinâmicas}

O trabalho de campo que deu origem a este artigo foi realizado na fronteira do Brasil com o Paraguai, nas cidades fronteiriças de Pedro Juan Caballero (Departamento de Amambay - Paraguai) e Ponta Porã (cidade pertencente ao 
estado de Mato Grosso do Sul). O contato com os moradores das duas cidades, bem como a realização de entrevistas e demais procedimentos metodológicos, ocorreram ao longo dos meses de outubro, novembro e dezembro de 2016 e janeiro de 2017.

A inserção no campo se deu pela via de relações sociais estabelecidas com informantes-chave em trabalhos anteriores. Esses interlocutores, além de contar suas experiências, apresentaram-nos pessoas que gostariam de participar da pesquisa, umas com o intuito de apenas colaborar com os pesquisadores, outras querendo relatar também suas vivências em relação ao tema das estratégias de acesso aos serviços de saúde naquela região de fronteira.

Houve também aqueles que por curiosidade se aproximavam e, em meio a uma conversa e outra que escutavam com mal disfarçado desinteresse, perguntavam "Isso aí vai virar livro? Porque se for eu também tenho coisa pra contar." As entrevistas se deram nas residências de alguns moradores, em bares e lanchonetes sugeridos como local do encontro pelos interlocutores; nos intervalos durante o horário de trabalho de alguns deles, depois do expediente e mesmo no decurso das atividades - como foi o caso dos vendedores ambulantes, dos comerciantes, dentre outras pessoas cujas atividades laborais não impossibilitavam a realização da entrevista ou mesmo de uma conversa informal.

As informações obtidas em relação às estratégias e táticas de acesso à saúde na fronteira em questão foram difíceis de coletar. O tema em si é bastante delicado e gerou certo receio nos interlocutores, principalmente aqueles que detinham - e detêm - dados relevantes para facilitar a melhor compreensão da dinâmica das categorias em análise. Algumas entrevistas foram marcadas, mas logo depois canceladas com desculpas que depois se soube serem justificadas pela desconfiança, por mais que houvesse reiteradas e detalhadas explicações a respeito da natureza do trabalho e do total anonimato dos depoimentos recolhidos.

A desconfiança é predominante na fronteira de Pedro Juan Caballero e Ponta Porã, como o é também em Ciudad del Leste e Foz do Iguaçu. Esses espaços conurbados carregam o estigma da ilegalidade e da violência, categorias cujas origens, trajetórias e representações têm mais de exagero midiático e fantasia histórica do que realidade efetiva. 


\section{Estratégicas, táticas e identidades: conceitos e paradigmas}

Michel de Certeau (1994), em seu livro A invenção do cotidiano, problematiza as concepções de estratégia e tática, notadamente aquelas acionadas pelos atores sociais quando da produção simbólica dos espaços sociais urbanos. As estratégias são entendidas pelo autor como cálculos operacionais, ou, ainda, mecanismos ideológicos de manipulação, que os sujeitos de poder e saber (Estado, empresa, exército, etc.) utilizam para produzir, e reproduzir, os espaços particulares de exercício de poder. Aqui, as estratégias - por meio das práticas cotidianas - acabam por reforçar os instrumentos coercitivos e reguladores do poder (Albuquerque, 2015).

No tocante às táticas, Certeau (1994) as compreende como se estas fizessem parte do cabedal de astúcias dos indivíduos, categorizando-as, então, como "a arte dos fracos" - possível de transfigurar a seu favor e de modo silente os sistemas disciplinares. Assim, na concepção do autor, as práticas cotidianas (estratégicas e táticas) configuram-se como locais e espaços de competição, embates e cisões que robustecem e corrompem as costumeiras configurações do poder e do saber.

As táticas, na concepção de Certeau (1994), podem ser entendidas como ações pensadas como substitutas provisórias de estratégias estatais e legalmente reconhecidas, mas ausentes em determinados momentos e circunstâncias. Exemplo dessa assertiva é a situação em que o estrangeiro indocumentado espera sua condição de saúde se agravar para buscar atendimento no país vizinho - o que configura uma tática, sabendo de antemão que tal país não pode lhe negar auxílio por conta do ordenamento jurídico vigente ali, isto é, as estratégias elaboradas pelo Estado para organizar o atendimento. A tática é, desse modo, como observa Certeau (1994, p. 100), "um movimento dentro do campo de visão do inimigo".

Para Scott (1985), em outra perspectiva teórica, tais táticas e astúcias dos fracos podem ser interpretadas como esquemas sub-reptícios de resistência, empregados pelas esferas economicamente subalternizadas como recursos para diminuir a exploração perpetrada pelos detentores do poder. Assim, essa insubordinação disfarçada, ou as armas dos fracos, emprega instrumentos diversos em sua ação, tais como: dissimulação, deserção, cumprimento falso, 
roubo, furto, ignorância fingida, calúnia, sabotagem, subserviência dissimulada, dentre tantos outros (Scott, 1985, p. 16). ${ }^{1}$

Tanto Certeau (1994) quanto Scott (1985) concordam com o fato de que os expedientes utilizados por aqueles alijados do acesso aos mais diversos tipos de bens e serviços, tantos os materiais quanto os imateriais, são instrumentos, armas, que facultam o acesso a esses bens e serviços subvertendo a ordem estabelecida pelos donos do poder, seja ele econômico, político, social ou cultural.

As estratégias elaboradas pelos Estados para organizar o acesso à saúde de seus nacionais são acessadas por estrangeiros por meio do emprego das táticas que, na conceituação de Certeau (1994), operacionalizam o acesso usando como instrumento as lacunas deixadas na armadura conceitual em que foram construídas as estratégias. Desse modo, as táticas adentram o universo das estratégias e com elas se confundem, impossibilitando sua imediata identificação, objetivos e mecanismos de acesso aos bens e serviços negados pelas estratégias legalmente instituídas.

É no interior da dinâmica das táticas de acesso à saúde na fronteira que as manifestações identitárias têm lugar. As identidades étnicas são evocadas para indicar os grupos étnicos aos quais se deve franquear o acesso aos serviços de saúde no Brasil, inclusão esta feita por vias tanto legais (estratégias) quanto ilegais (táticas).

A propósito da menção aos grupos étnicos, e aos desdobramentos identitários que deles emergem, estes têm suas conceituações fortemente aceitas nos trabalhos do antropólogo norueguês Fredrik Barth, notadamente naquele intitulado Grupos étnicos e suas fronteiras, originalmente publicado em 1969. No texto em tela, o autor discute questões sobre concepções identitárias, etnicidade e a criação de fronteiras étnicas.

Um grupo étnico é, grosso modo, composto por um conjunto de pessoas que se identificam umas com as outras, ou são identificadas por membros de outros grupos, tomando por base as similitudes socioculturais e/ou biológicas aparentes, sejam elas factuais ou pressupostas. Desse modo, o grupo tem sua organização voltada para a interação e categorização de si mesmo e dos

1 "I have in mind the ordinary weapons of relatively powerless groups: foot dragging, dissimulation, desertion, false compliance, pilfering, feigned ignorance, slander, arson, sabotage, and so on" (Scott, 1985, p. 16). 
outros, isto é, constrói fronteiras culturais que lhe permitem a clara definição entre o "eu" e o "outro" no interior da dinâmica relacional à qual está exposto (Barth, 2000).

Na concepção do autor, a etnicidade - definida como condição ou consciência de pertença a um dado grupo étnico - relaciona-se intrinsecamente aos aspectos organizacionais dos grupos étnicos, compreendidos por Barth (2000) como padrões de atribuição de sentido e reconhecimento entre os diversos atores de um dado agrupamento social.

A etnicidade, ou o sentimento de pertença, é, então, expressão das premissas identitárias, agregadoras ou contrastivas, adotadas pelos grupos étnicos no processo de interação sociocultural a que estes são levados, consciente ou inconscientemente, a participar de diversas formas.

\section{O acesso ao SUS na fronteira Brasil/Paraguai: Pedro Juan Caballero e Ponta Porã em perspectiva}

Nas cidades fronteiriças de Pedro Juan Caballero e Ponta Porã podem se verificar desacordos entre brasileiros e paraguaios, especificamente em questões referentes à identidade étnica e à identidade nacional (Nascimento, 2012; Sprandel, 2006). Todavia, essas categorias contribuem com o distanciamento entre os dois povos em outras regiões do Paraguai, tais como "[...] nas cidades de Santa Rita, Santa Rosa, San Alberto, Mbaracayu (Departamento Alto Paraná) e Salto del Guayra (Canindeyu) [...]" (Sprandel, 2006, p. 142).

Essas dissenções são expressas de várias maneiras no cotidiano das fronteiras entre Brasil e Paraguai; a mais perceptível se dá por meio das denominações identitárias de caráter étnico e nacional, tais como fronteiriço, brasiguaio, brasileiro, paraguaio, estrangeiro, paraguaio legítimo e puro, dentre outras (Nascimento, 2014; Sprandel 2006).

No campo da saúde, tais desacordos também estão presentes. Gera desconforto nos brasileiros a procura, por parte dos paraguaios, dos serviços de saúde no Brasil, dado acreditarem, erroneamente, que essa busca onera irremediavelmente o sistema de saúde na fronteira (Albuquerque, 2012; Tamaki et al., 2008).

Em que pese a importância do aporte econômico alocado na região para o atendimento dos usuários, a ausência de recursos não é o único problema na 
dinâmica do acesso à saúde na fronteira de Pedro Juan Caballero e Ponta Porã. Em verdade, faltam políticas de integração eficazes para resolver os entraves relacionados ao acesso aos serviços, é necessário um esforço cooperativo entre as nações envolvidas no sentido de elaborar estratégias e políticas públicas para pensar soluções viáveis no que diz respeito à problemática em questão.

Um dos programas instituído para tentar solucionar os problemas atinentes à saúde na fronteira é o Sistema Integrado de Saúde das Fronteiras, conhecido também como SIS Fronteiras. Lançado oficialmente em setembro de 2005 , na cidade de Uruguaiana (RS), esse programa objetiva colaborar com a organização e a consolidação dos sistemas locais de saúde nos municípios fronteiriços brasileiros, bem como viabilizar a associação de ações e serviços de saúde na região de fronteira (Brasil, 2005).

Para sua implantação foram previstas três fases de desenvolvimento, que também correspondem ao repasse de recursos financeiros aos municípios que aderirem ao projeto. A ideia central do SIS Fronteiras é promover a integração de ações e serviços de saúde na região de fronteira, contribuindo para a organização e o fortalecimento dos sistemas locais de saúde nos municípios fronteiriços (Brasil, 2005).

O projeto pretende, desde que foi instituído, estimular o planejamento e a implantação de ações e acordos entre os países que compartilham fronteiras, por meio de um diagnóstico da situação de saúde dessas regiões. Para isso, ressalta a necessidade de mensurar alguns aspectos, entre eles: a) aspectos socioeconômicos; b) aspectos geográficos; c) aspectos epidemiológicos, sanitários, ambientais; e d) aspectos assistenciais. Esse projeto abrange inicialmente 121 municípios da faixa de fronteira brasileira (Brasil, 2005).

Para Nogueira e Giménez (2010, p. 5), tomando como ponto de partida de suas análises "a ótica governamental", com a efetiva instalação desses projetos, outras forças políticas poderiam ser incorporadas e instadas a envolver-se com o compromisso de continuidade dessa integração. O projeto objetiva também estabelecer articulações com instituições de ensino e pesquisa, buscando auxiliar, no início das atividades do projeto, a produção efetiva do diagnóstico local.

O problema na formulação do SIS Fronteiras, sem nenhum demérito no tocante à relevância do diagnóstico sugerido pelo programa, repousa em aspectos contraproducentes do ponto de vista das suas diretrizes, como analisam Nogueira e Giménez (2010, p. 5): 
No plano ético-político, a ideia do SIS Fronteiras inscreve-se não em um esforço de articulação dos sistemas de saúde entre os países, mas tende a manter uma posição hegemônica, fortalecendo ações unilaterais e dificultando a harmonização das ações e serviços de saúde. Em termos de implementação, o fato de ser um programa pouco discutido com os gestores nacionais e não nacionais contribuiu para as dificuldades de sua apreensão, favorecendo o destaque e a anuência ao programa tendo em conta apenas a possibilidade de ampliação de recursos para o município.

Nas áreas de fronteira, as dificuldades em manter o sistema "SUS um direito de todos!" são maiores, pois não há regulamentação para organizar, orientar, definir e otimizar o uso dos recursos e serviços de saúde pública e, assim, promover o acesso com equidade à população (Viegas; Penna, 2013). A questão da falta de aporte de recursos econômicos é um dos principais obstáculos ao atendimento de estrangeiros, como também de brasileiros, que acorrem ao Sistema Único de Saúde (SUS) no Brasil, como já verificaram Preuss $(2007,2011)$ e Agustini (2008).

Para além dos discursos políticos não se verificam, em se tratando da faixa de fronteira aqui estudada, políticas públicas efetivas de integração de ações de saúde. O papel do Estado brasileiro é obscurecido no que diz respeito à efetividade de suas políticas públicas voltadas às fronteiras atinentes à saúde. Tal fato se deve, em parte, segundo Nogueira e Giménez (2010), às atitudes de gestores que compreendem ser o direito de acesso aos serviços prerrogativa de brasileiros e, por conta disso, dificultam por meio de instrumentos burocráticos o atendimento aos estrangeiros, levando-os à elaboração dos estratagemas aqui aludidos.

Em que pesem os esforços envidados na tentativa de contribuir com a melhoria do atendimento à população fronteiriça, principalmente com a descentralização do sistema de saúde brasileiro ainda em curso, percebe-se a presença incômoda e constante de obstáculos à implantação de uma rede de serviços eficiente e igualitária. Os contratempos para um planejamento de ações mais eficazes não foram alcançados ainda, bem como a construção de mecanismos para captar e alocar devidamente os financiamentos (Nogueira; Fagundes, 2014). 


\section{Ponta Porã e Pedro Juan Caballero: contexto geográfico, histórico e sociocultural}

A faixa de fronteira do Brasil tem proporções significativas: 15.719 quilômetros, que equivalem a $27 \%$ do território nacional. Possui extensão de 150 quilômetros de envergadura equidistante ao traçado limítrofe terrestre do país. Nessa área estão contidos 588 municípios, em 11 estados que fazem fronteira com dez países da América do Sul, em que vivem aproximadamente dez milhões de pessoas (Gadelha; Costa, 2007).

A cidade de Pedro Juan Caballero localiza-se a nordeste da República do Paraguai. Seu contingente populacional é de aproximadamente 88.029 habitantes, de acordo com os dados da Dirección General de Estadística, Encuestas y Censos (DGEEC). A região que circunscreve a cidade tem predominância do clima tropical com temperatura variando entre $22^{\circ} \mathrm{C}$ e $23^{\circ} \mathrm{C}$ (Dirección General de Estadística, Encuestas y Censos, 2002).

Pedro Juan Caballero se destaca pela atividade turística na região, principalmente o turismo de compras em que predomina o comércio de produtos importados. Esses produtos chegam ao Brasil vindos de várias partes do mundo, mas em sua maioria da China (Pinheiro-Machado, 2009). O comércio na região teve início no ".... final do século XIX quando a cidade passa a ser utilizada como um lugar de descanso para as caravanas que transportavam erva-mate até Concepción. A partir da década de 60 o comércio se fortalece, consolidando o turismo de compras" (Martins; Banducci Júnior, 2009, p. 3).

Ponta Porã compreende uma superfície total de $5.328,621 \mathrm{~km}^{2}$, sendo a superfície urbana de $13,715 \mathrm{~km}^{2}$, possuindo 79.173 habitantes - em que $89 \%$ residem na zona urbana e $11 \%$, na zona rural. Situa-se na região sudeste do estado de Mato Grosso do Sul, tendo seus limites com os municípios de Dourados, Bela Vista, Antônio João, Jardim, Guia Lopes da Laguna, Maracaju, Dourados, Lagoa Carapã, Aral Moreira, com o estado do Paraná e a República do Paraguai (Instituto Brasileiro de Geografia e Estatística, 2011). A exemplo de Pedro Juan Caballero, o clima predominante em Ponta Porã é o tropical, ou tropical de altitude, como ensinam os geógrafos. A temperatura média varia de $20,6^{\circ} \mathrm{C}$ a $22^{\circ} \mathrm{C}$. No decorrer do ano, o mês mais quente é o de fevereiro, com temperatura média de $23,6^{\circ} \mathrm{C}$, e o mês com temperaturas mais baixas é o de julho, com média de $16,4^{\circ} \mathrm{C}$. 
No município de Ponta Porã, a economia tem suas atividades direcionadas à agricultura e à pecuária. No entanto, há que se levar em consideração a relevância da lavoura na região - especificamente trigo, soja e milho. Essa importância é mensurada de acordo com a posição obtida pela cidade de Ponta Porã ( $406^{\circ}$ maior potencial de consumo) em relação às cidades brasileiras com maior índice de consumo (IPC Marketing, 2010).

No que diz respeito à oferta de serviços de saúde na faixa de fronteira em análise, Ponta Porã conta com três hospitais, dos quais dois são públicos e um, explorado pela iniciativa privada. Somam-se a essas instituições 13 outras repartições, distribuídas entre unidades básicas e postos de saúde (Brasil, 2016). No caso de Pedro Juan Caballero, a cidade dispõe um hospital regional, e um posto de saúde e dez unidades de atendimento à saúde da família (Paraguay, 2016).

A propósito das peculiaridades que envolvem a região em estudo, Pedro Juan Caballero e Ponta Porã se destacam ainda, como já mencionado, por serem categorizadas como cidades-gêmeas. Para a conceituação dessa categoria, o Ministério da Integração Nacional, por meio da portaria $\mathrm{n}^{\circ} 125$ de 21 de março de 2014, estabelece nos seus artigos $1^{\circ}$ e $2^{\circ}$ que cidades-gêmeas são aquelas em que o contingente populacional não ultrapasse dois mil habitantes e em que os municípios são cindidos pela linha de fronteira, seca ou fluvial, contendo ou não infraestrutura, que “[...] apresentem grande potencial de integração econômica e cultural, podendo ou não apresentar uma conurbação ou semi-conurbação com uma localidade do país vizinho [...]" (Brasil, 2014). Outra preocupação presente na conceituação diz respeito às manifestações dos problemas peculiares à fronteira, "[...] que aí adquirem maior densidade, com efeitos diretos sobre o desenvolvimento regional e a cidadania" (Brasil, 2014).

A fronteira, nos seus diversos aspectos, tem despertado o interesse da academia e de seus representantes. Estes têm envidado esforços de caráter científico na tentativa de compressão dos inúmeros e complexos fenômenos que têm tido lugar nesses espaços, independentemente das denominações acadêmicas e divisões disciplinares tão comuns às universidades e seus departamentos. Desse modo, tem-se que as contribuições acadêmicas que têm a fronteira como foco têm sido tributárias das áreas das ciências biológicas, das ciências humanas, das ciências sociais e sociais aplicadas, das ciências exatas, das ciências da saúde e, não raro, de uma perspectiva inter ou multidisciplinar (Nascimento, 2012). 
Os antropólogos tendem, no que diz respeito à fronteira como objeto de estudo, a abordar os aspectos que privilegiam as questões culturais e seus desdobramentos simbólicos, a exemplo do trabalho de Leach (1996) acerca das fronteiras da Birmânia; dos trabalhos de Grimson (2003) sobre a fronteira Brasil-Argentina; Alvarez Júnior (1995) e as pesquisas que desenvolve na fronteira México-Estados Unidos; Banducci Júnior (2011) e Nascimento (2012) e suas investigações sobre a fronteira Brasil/Paraguai, notadamente Pedro Juan Caballero e Ponta Porã, dentre tantos outros. A preocupação centra-se nas diversas e divergentes formas que os indivíduos têm de vivenciar a cultura e suas determinantes no processo do devir histórico.

A realidade sociocultural da fronteira de Ponta Porã e Pedro Juan Caballero é extremamente complexa, dada a coexistência nesse espaço limítrofe, nem sempre harmoniosa, de pessoas, etnias, idiomas, ideias e ideologias, o que acaba por gerar culturas de fronteira, que por sua vez se transformam em fronteiras da cultura (Alvarez, 2010). No entanto, não são fronteiras culturais que se repelem, enquistadas em si mesmas; são fronteiras que estruturalmente se complementam e se hibridizam no interior e nas bordas dos limites territoriais legalmente constituídos (García Canclini, 1997).

No tocante à área da saúde, esta tem sido alvo de interesse no que diz respeito aos serviços e ações desenvolvidos nos municípios partícipes do Mercado Comum do Sul, Mercosul, posto que, afora as intenções econômicas do bloco, constata-se um relevante recrudescimento do contingente de indivíduos de nacionalidade estrangeira que buscam utilizar os serviços e ações de saúde oferecidos no Brasil (Nogueira et al., 2015).

Contudo, os cidadãos estrangeiros - ainda que residentes no país - não são detentores de direitos nacionais no que se refere à cidadania e ao acesso aos serviços prestados na área de saúde no território brasileiro, o que traz certo incômodo aos responsáveis pelos sistemas regionais. Esses administradores veem-se pressionados a prestar atendimento, quando possível, à população alóctone, embora não tenham em sua estrutura de ação capacidades técnicas e receita pecuniária para tanto.

A demanda estrangeira pelos serviços ofertados pela área da saúde nas fronteiras brasileiras não é tão expressiva como querem fazer crer alguns gestores e autoridades alocados nas fronteiras. Tamaki et al. (2008) observam que apesar dos discursos desses atores sociais enfatizarem que do orçamento da saúde 
alocado para atender a região $40 \%$ são gastos com atendimento aos estrangeiros, as informações não se verificam, visto que os dados colhidos para a confecção de um diagnóstico de saúde nos municípios de fronteira de Mato Grosso do Sul apontam a inexpressividade dessa demanda.

Todavia, apesar da demanda não ser tão expressiva, a ponto de onerar de maneira irremediável os custos relacionados à saúde no município, é inegável que ela existe e, portanto, deve ser levada em consideração quando da alocação de recursos ou da elaboração de políticas públicas que tenham como objeto o acesso à saúde aos estrangeiros em regiões fronteiriças.

Em face dessa situação, identificam-se obstáculos no sentido de fornecer o acesso digno à saúde prescrito pela Constituição Federal de 1988, ou seja, acesso de maneira universal e integral. O Mercosul tem, na medida de suas possibilidades e sempre procurando respeitar as soberanias nacionais, instituído ações de notável iniciativa no tocante ao campo da saúde. Sob sua égide e influência têm-se elaborado diversas intervenções, notadamente aquelas voltadas ao combate e à prevenção de doenças infectocontagiosas e de vigilância sanitária. Dessa maneira, no que diz respeito à prestação de serviços em saúde, nota-se que os contratos que se sucedem entre os governos concorrem no sentido de que o estrangeiro possa ter livre acesso ao atendimento público em quaisquer das nações constituintes da coalizão denominada Mercosul (Nogueira et al., 2015).

Existem razões que podem contribuir e influenciar na busca pelos serviços de saúde no Brasil. Apesar de a experiência na área de saúde por meio do SUS não ser uma das melhores, ainda é uma boa opção àqueles que não têm muitas alternativas. Um desses fatores é a razoável facilidade no acesso, que atrai os segmentos populacionais das nações economicamente mais vulneráveis. Assim, diante da precariedade de condições socioeconômicas e infraestruturais em que se encontram, recorrem ao Brasil, através do SUS, em busca de atendimento. Tal fato acaba por se refletir de maneira contundente no processo organizacional e estruturante do sistema de saúde dos municípios fronteiriços e, por conseguinte, na vida sociocultural e econômica de suas populações.

Contudo, apesar da questão da escassez de recursos ser um dos motivos mais alegados pelos entrevistados, existem outras razões presentes na dinâmica da migração de paraguaios para o Brasil, especialmente em busca de serviços de saúde, dentre elas a contiguidade geográfica (isso porque os distritos 
paraguaios encontram-se distantes dos centros de saúde); a relativa facilidade de acesso aos meios de transporte; a confiança depositada nos serviços de atendimento à saúde do país; a gratuidade do Sistema Único de Saúde e a garantia da continuidade do atendimento em casos complexos; e o atendimento compulsório em casos de urgência. Questões que denotam a fragilidade do Paraguai em atender seus cidadãos, haja vista a falta de infraestrutura e ausência de políticas públicas pensadas para dirimir os inúmeros problemas de acesso à saúde naquele país (Azevedo, 2015).

Nas localidades que abrangem a fronteira, os serviços ofertados relacionados à saúde adquirem uma relevância e uma dimensão ímpares na vida diária dos indivíduos que moram e circulam nesses espaços, notadamente no que tange à possibilidade de facultar ou restringir o acesso desses sujeitos, colaborando ou não no sentido de garantir direitos à saúde.

Segundo Giovanella et al. (2007), baseando-se em dados coletados junto aos secretários municipais de Saúde nas fronteiras do Brasil, existe uma disparidade, por parte dos estrangeiros, no que tange à busca de serviços de saúde ofertados pelo SUS na fronteira. Conforme as informações repassadas por esses secretários, existe uma procura de atendimento no SUS em 75\% dos municípios, sendo que tal procura se intensifica de maneira considerável em $36 \%$ das regiões.

De acordo com os autores citados acima, as demandas com maior incidência tendem a ocorrer em regiões cujos limites alcançam o Paraguai. Para 70\% dos secretários municipais, tais demandas de estrangeiros atingem nove dos 12 serviços listados na pergunta a eles submetida sobre o "tipo de atendimento buscado freqüente e muito freqüentemente por estrangeiros no SUS do município por país de fronteira, segundo os secretários de saúde. Municípios brasileiros de fronteira com a Argentina, o Paraguai e o Uruguai, 2005" (Giovanella et al., 2007, p. 258-259).

No tocante à acessibilidade, Travassos e Martins (2004) indicam duas dimensões: a sócio-organizacional (em que estão presentes a oferta de serviços e suas principais características); e a geográfica (que se relacionam com a noção de espaço, em que existe a possibilidade de se medir as variáveis atinentes a distâncias, sejam elas lineares, de tempo e locomoção, custo de viagem, entre outras).

De acordo com Pereira (2000), o acesso à saúde traz em sua dinâmica características multifacetadas, dentre elas as de caráter econômico, social e cultural 
que, em face das complexidades inerentes a essas categorias, extrapolam as esferas da assistência à saúde. No que diz respeito ao uso dos serviços de saúde, é inegável reconhecer a influência determinante de condições socioeconômicas e culturais, que se interpenetram aos aspectos intersetoriais arraigados à estrutura política de cada país, bem como aos espaços de poder que as caracterizam. Contudo, a concretização de um projeto em que a equidade é o mote não pode deixar de levar em consideração de que a ênfase no que diz respeito à acessibilidade dos serviços de saúde constitui-se um elemento de suma importância (Nogueira; Silva, 2007).

Não são somente os estrangeiros que sofrem com o serviço ofertado pelo Sistema Único de Saúde no Brasil. Imigrantes brasileiros que vivem no Paraguai - os denominados brasiguaios - enfrentam problemas de aceitação, além dos relacionados à prestação de serviços de saúde, quando acorrem aos postos de saúde localizados no Brasil. Albuquerque (2012, p. 25) traz um exemplo da ocorrência desse tipo de situação na fronteira Brasil/Paraguai:

O passo inicial para ser atendido no sistema público de saúde no Brasil é marcar uma primeira consulta em uma UBS. Uma das unidades básicas mais procuradas pelos imigrantes brasileiros e seus descendentes que vivem no Paraguai é a do Jardim América, cerca de $1 \mathrm{~km}$ da Ponte da Amizade, limite internacional entre o Brasil e o Paraguai. Pela manhã, percebemos que a maioria dos carros estacionados em frente a esse posto de saúde tem placas paraguaias. A população próxima a esse estabelecimento de saúde, muitas vezes, reclama que o posto está sempre lotado por causa dos brasiguaios. Embora não seja a UBS mais próxima da Ponte da Amizade, é onde existem mais especialidades médicas e também odontologia.

No tocante ao acesso aos serviços de saúde pelos brasiguaios, a situação é um pouco mais complicada. Para ser atendido pelo SUS no Brasil é necessário estar cadastrado no Sistema de Informações em Saúde (SIS) por meio do Cartão Nacional de Saúde, o Cartão SUS - instituído pela portaria $n^{\circ} 1.560$, de 29 de agosto de 2002 (Brasil, 2002). Esse instrumento - criado pelo governo federal objetiva vincular os seus usuários às ações e serviços de saúde realizados pelo SUS, bem como identificar as pessoas que foram atendidas e a região do país em que se deu o atendimento. 
Todavia, o Cartão SUS tem sua validade restrita ao Brasil, sendo seu uso circunscrito aos municípios em que o titular do cartão comprove residência. Portanto, o direito de posse e utilização do Cartão SUS é prerrogativa de brasileiros e estrangeiros que comprovem residir no país, conforme consta da redação do artigo $4^{\circ}$ da lei supracitada. ${ }^{2}$ Contudo, o artigo $5^{\circ}$ do mesmo documento assevera que a falta do cartão não gera impedimento ao atendimento de brasileiros e estrangeiros não residentes no país. Caso se comprove o não atendimento por conta da ausência do Cartão SUS, os envolvidos incorrerão no crime de omissão de socorro. ${ }^{3}$

No Brasil, alguns dispositivos elaborados para organizar e melhor atender aos brasileiros - no que respeita ao acesso à saúde - têm servido como entraves ao atendimento de estrangeiros. Dentre essas restrições, a criação do Cartão SUS, condição exigida ao público para viabilizar o atendimento, é uma das mais intransponíveis barreiras impostas aos estrangeiros. Outro empecilho ao atendimento de estrangeiros no país consiste no fato de que boa parte dos gestores acredita que atendimento pelo sistema público é prerrogativa dos brasileiros. Assim, acabam recrudescendo as medidas de controle e/ou mesmo negando o acesso, o que os leva a apelar a táticas - instruídos por outros que já passaram pela mesma situação (Silva, 2006).

As opiniões sobre o direito ao acesso à saúde no Brasil por parte dos estrangeiros não são unânimes. Para alguns brasileiros, entrevistados por Preuss (2011, p. 15), sobre o atendimento: “'Somente em casos de emergência eles têm direito senão não pode atender.'; 'Se vem mal, se passa mal é atendido (emergência/urgência)." Os depoimentos enfatizam o caráter urgente do atendimento, notadamente as situações em que a presteza no socorro determina se o paciente vive ou morre. ' $O$ direito à saúde é uma questão de cada país; quem não é daqui (Brasil), não tem direito, mas numa situação de emergência, daí tem."' No entanto, as opiniões se dividem quando os casos

2 “Todos os brasileiros, natos ou naturalizados, bem como os estrangeiros com residência permanente no país, têm direito ao CARTÃO SUS, independentemente de sua idade" (Brasil, 2002, art. $4^{\circ}$ ).

3 "A ausência do CARTÃO SUS não poderá impedir o atendimento à pessoa brasileira ou estrangeira, com qualquer tipo de visto de entrada no país, em qualquer unidade de saúde integrante do Sistema Único de Saúde, sob pena do cometimento de crime de omissão de socorro" (Brasil, 2002, art. $5^{\circ}$ ). 
não são urgentes, ou seja, não envolvem a possibilidade de morte iminente caso não haja atendimento: “'O que não é emergência não é atendido pelo SUS, só particular.'; 'O direito é igual ao nosso; o exercício é igual, são pessoas como qualquer outra; gratuito.'; 'Por direito deveriam primeiro procurar no país deles."

Na concepção dos interlocutores de Preuss (2011) a respeito do direito ao acesso à saúde por parte dos estrangeiros, pode-se ver a característica dicotômica de opiniões sobre o tema. Alguns entrevistados assumem o direito à saúde para além dos casos emergenciais; outros o identificam atrelados às questões referentes à nacionalidade:

"Direito à saúde é pra todos. Direito humano é um só."; "Todo o ser humano tem direito a atendimento; o que não é certo é tirar atendimento dos brasileiros que ficam na fila do atendimento e outros tiram a vaga. São atendidos."; "Creio que seja bem atendido, é garantido, atendem igual, são todos humanos."; "Se a saúde é um direito de todos deve ser garantida a todos, não importa quem." (Preuss, 2011, p. 15).

A fronteira não se limita aos marcos nacionais erigidos para separar faixas de territórios legalmente divididos. Como observa Goettert (2013), uma fronteira de maior expansão, mais perceptível aos sentidos, pode obscurecer fronteiras de menor proporção, menos visíveis, menos tangíveis (subjacentes, veladas). Desse modo, por trás da falácia dos povos "irmãos", da propalada irmandade sem conflitos entre brasileiros e paraguaios, encontram-se as fronteiras "menores" mencionadas por Goettert.

No caso do acesso à saúde, bem como em outros casos, essas pequenas fronteiras se expressam nas representações verbalizadas cotidianamente, tanto por brasileiros quanto por paraguaios. O incômodo demonstrado pelos informantes de Albuquerque (2012) e Preuss (2011) denota o quão intrincadas são as relações que têm o acesso à saúde como mote.

A propósito da menção às representações oriundas da população fronteiriça, notadamente aquela parcela que faz uso efetivo dos serviços de saúde ofertados pelo SUS no Brasil, há uma predominância nas pesquisas realizadas até então - com raras exceções - de se privilegiar os depoimentos e as representações advindas daqueles que, de uma maneira ou de outra, têm vínculos com o 
Estado nas suas mais diversas formas, como pode ser observado nos trabalhos de Peiter (2005), Giovanella et al. (2007) e Tamaki et al. (2008).

Por que a preferência por esses atores sociais? A resposta talvez possa ser encontrada na pouca importância atribuída à opinião das pessoas oriundas de estratos culturais em que se crê haver menos esclarecimento no tocante a certos temas. $\mathrm{Ou}$, ainda, tal preocupação não entra na agenda de alguns pesquisadores, talvez por conta do condicionamento ideológico recebido durante o processo de formação profissional - ao qual todos estamos expostos em menor ou maior grau -, ou por não se constituir como objetivo de investigações solicitadas por órgãos governamentais ou não governamentais.

\section{O acesso à saúde e sua dinâmica na fronteira: estratégias, táticas e repercussões identitárias em Pedro Juan Caballero e Ponta Porã}

A respeito das dificuldades de acesso, principalmente por conta da documentação exigida para ser atendido, as estratégias são as mais mirabolantes, e por vezes arriscadas. Uma tática muito utilizada consiste em tomar de empréstimo documentos que comprovem residência em território brasileiro. Esses documentos são aqueles que não possuem fotografias acompanhando os antropônimos, tais como extratos de tarifas de energia elétrica, de conta d'água e o certificado de contribuição de pessoa física (Nogueira; Simionatto; Silva, 2003).

No parágrafo acima se vê o grau de heterogeneidade que envolve as inter-relações entre brasileiros e paraguaios na fronteira. Enquanto alguns brasileiros não veem com bons olhos o acesso dos paraguaios ao sistema de saúde do Brasil, outros lhes emprestam, ou alugam, documentos para que possam viabilizar o acesso. Uma outra característica do acesso à saúde na região de fronteira diz respeito às redes de solidariedade existentes nesses contextos (Preuss, 2011).

No caso específico da fronteira situada entre Pedro Juan Caballero e Ponta Porã, para aqueles que não conseguem comprovar residência no Brasil a solução é acionar as redes de solidariedade às quais estão vinculados: parentes; amigos; namorados e namoradas. Assim, conseguem comprovar residência no Brasil e serem atendidos, bastando apresentar uma declaração assinada por 
morador brasileiro atestando que o indivíduo portador da declaração reside com o declarante. ${ }^{4}$ Essa tática, apesar das possíveis sanções legais caso se comprove fraude, não apresenta problemas quanto à sua utilização, já que o estado de Mato Grosso do Sul não dispõe de efetivo para fiscalizar as declarações apresentadas como comprovação de domicílio.

Em visitas realizadas à cidade de Ponta Porã em dezembro de 2016 e janeiro de 2017, em entrevistas realizadas com os moradores, tanto de Ponta Porã quanto de Pedro Juan Caballero, foi possível perceber, no discurso dos interlocutores, a presença dessas relações no cotidiano de acesso à saúde naquela fronteira específica. Quando um paraguaio é inquirido a respeito de como se consegue acesso aos serviços do SUS no Brasil sem possuir o respectivo cartão, as respostas são reveladoras:

É fácil. Por exemplo, se você tem um conhecido aqui no Brasil, em Ponta Porã, você explica a situação pra ele, diz que é caso de doença, ninguém nega, sabe. Vocês [brasileiros] são muito companheiros nessa parte. Eu mesmo já usei endereço de vários conhecidos aqui, nunca tive problema, ninguém nunca falou nada. (Entrevistado $\mathrm{n}^{\circ} 1$, paraguaio, vendedor ambulante em Pedro Juan Caballero, entrevista realizada em Ponta Porã).

Do ponto de vista dos brasileiros, pelo menos aqueles com os quais se estabeleceu contato, essa realidade do emprego das táticas de acesso é bastante aceitável, mas com condições, como observou um interlocutor:

4 Desde 2011 está em vigor no Brasil a lei $\mathrm{n}^{\circ}$ 4.082/2011, que trata da inexigibilidade de comprovante de residência. Conforme a nova regra, uma declaração de próprio punho, isto é, redigida pelo próprio interessado em seu favor ou em favor de outrem, suprirá a exigência de comprovante de residência. No artigo $3^{\circ}$, a nova lei ainda deixa bem claro que recusar a declaração escrita pelo próprio cidadão como comprovante de endereço pode causar advertência e até multa de 150 UFERMS, que pode ser dobrada em caso de reincidência (cf. Brasil, 2011). A lei em questão enfatiza a necessidade de inclusão na declaração manuscrita do conhecimento do autor de que a falsidade da informação incorre no crime de falsidade ideológica, tipificado no Código Penal brasileiro, cuja redação informa: “Falsidade ideológica Art. 299. Omitir, em documento público ou particular, declaração que dele devia constar, ou nele inserir ou fazer inserir declaração falsa ou diversa da que devia ser escrita, com o fim de prejudicar direito, criar obrigação ou alterar a verdade sobre fato juridicamente relevante: Pena: reclusão, de um a cinco anos, e multa, se o documento é público, e reclusão de um a três anos, e multa, se o documento é particular" (cf. Greco, 2016, p. 1524, grifo do autor). 
Rapaz, é tudo ser humano igual a gente, e quando o problema é de saúde, não tem nem o que dizer, né? Tem que ajudar mesmo, se for doença, né? Mas só acho certo ajudar se for pai de família, trabalhador, gente honesta. Agora se for por motivo de bandidagem, briga, essas coisas, num tem que atender coisa nenhuma, eles que procurem o país deles. Agora se é pai de família, tá doente, ou alguém da família dele, aí sim. (Entrevistado $n^{\circ} 2$, brasileiro, porteiro, entrevista realizada em Ponta Porã).

Aqui, a condição imposta é "ser pai de família, trabalhador, gente honesta", do contrário, o atendimento não poderia ser realizado. Isso pode ser percebido no depoimento do entrevistado $\mathrm{n}^{\circ} 2$, quando estabelece no seu sistema de valores quem deve e quem não deve ser atendido. Aqui, está presente certa empatia de classe, isto é, os brasileiros aceitam que seja atendido, independentemente da nacionalidade, o indivíduo que com eles se assemelha em condições socioeconômicas e morais. As categorias elencadas para viabilizar o acesso são "pai de família, trabalhador, gente honesta", o que na interpretação dos interlocutores equivale a dizer que são pessoas “iguais a nós".

O mesmo não corre com aqueles que não são "como nós", ou seja, aqueles reputados como bandidos e arruaceiros. Assim, na opinião do entrevistado $n^{\circ} 2$, estes não devem ser atendidos pelo sistema de saúde brasileiro, ainda que estejam à beira da morte, haja vista que sua situação não foi imposta por problemas de saúde oriundos da própria condição humana, mas por decisões e escolhas feitas conscientemente.

Eu não acho certo isso. O cara apronta e depois que se ferra quer que a gente atende ele; e o pior que a lei obriga, né? Eu acho que se o cara que vem de fora e se mete em confusão aqui [Brasil] não tem de ser atendido e pronto. Agora você vê, e se quando o médico tiver atendendo um bandido e um trabalhador precisar ser atendido também? E daí? Por isso que eu não concordo. (Entrevistado $n^{\circ} 2$, brasileiro, porteiro, entrevista realizada em Ponta Porã).

Comungam da mesma opinião alguns paraguaios, moradores de Pedro Juan Caballero. "Se não for por motivo de doença, não devia atender, não. Sabe por quê? Porque não é justo com quem é direito, honesto, trabalhador", afirma um interlocutor quando perguntado sobre sua opinião a respeito do atendimento aos paraguaios "bandidos" pelo sistema de saúde brasileiro. 
Chama atenção no depoimento de alguns interlocutores a questão da identidade contrastiva teorizada por Fredrik Barth (2000). O contraste identitário é expresso pela relação trabalhador/pai de família e bandido/arruaceiro, em que se tem esta última figura como contraponto da primeira. Aqui, a identidade do brasileiro morador da fronteira, aquele que é pai de família e trabalhador, é contrastada com a representação que se tem do paraguaio que é bandido e arruaceiro, e que, portanto, não merece atendimento nem em situação de risco de morte. O que equivale a dizer que "não sendo igual a nós, não merece o mesmo tratamento", o que não se aplica ao paraguaio que é considerado como trabalhador e pai de família, já que este, seguindo os preceitos morais estabelecidos pelos brasileiros na faixa de fronteira, é "igual a nós", isto é, partilha a mesma condição socioeconômica e é regido pelo mesmo código moral em que trabalho e família são as bases estruturais.

O mesmo pode se dizer a respeito da identidade autoatribuída pelo entrevistado $\mathrm{n}^{\circ} 3$, (paraguaio, vendedor ambulante), “direito, honesto e trabalhador", qualidades ausentes naqueles paraguaios considerados criminosos. Nos termos da teoria da identidade contrastiva de Barth (2000), equivale a dizer do outro, ainda que da mesma nacionalidade, que este não pertence à mesma esfera identitária, situando-se, assim, fora do círculo simbólico e classificatório em que se localizam, e são localizados, indivíduos com a mesma pertença identitária autoatribuída e socialmente reconhecida - e por isso membros de um mesmo grupo étnico, não em função do seu local de nascimento, mas em função dos valores socioculturais e morais que comungam entre si.

Nesse sentido, é pertinente a análise de Barth (2000, p. 32) a respeito da importância dos valores socioculturais elencados para representar as identidades: "Uma vez que pertencer a uma categoria étnica implica ser um tipo de pessoa e ter determinada identidade básica, isto também implica reivindicar ser julgado e julgar-se a si mesmo de acordo com os padrões que são relevantes para tal identidade."

Tal identidade étnica torna-se mais tangivel quando verbalizados os discursos de caráter identitário, elaborados tendo por base a alteridade e expressos pela via dos contrastes. Desse modo, as identidades étnicas, tanto brasileiras quanto paraguaias, só se movimentam orientadas por uma singularidade, que se estrutura em agrupamentos dicotômicos do tipo Nós/Eles (Nascimento, 2012). 
As categorias trabalhador e pai de família são acionadas para compor uma identidade étnica que vai além da fronteira Brasil/Paraguai e além da noção de nacionalidade. Tanto brasileiros quanto paraguaios se reconhecem pertencentes ao grupo - independentemente da sua nacionalidade - dos trabalhadores e pais de família e, a esse grupo, é franqueado a acesso aos serviços de saúde por meio do SUS no Brasil, seja esse acesso possibilitado por meio das estratégias ou das táticas.

Nesse sentido, Barth (2000) analisa as categorias étnicas como possíveis reservatórios organizacionais, passíveis de hospedar conteúdos diversos e em diferentes quantidades e aspectos oriundos dos mais diversificados sistemas socioculturais. Podem, tais categorias étnicas, "ter grande importância, mas não necessariamente; podem colorir toda a vida social, mas também ser relevantes apenas em determinados setores de atividade" (Nascimento, 2012, p. 47). Desse modo, "as características a serem efetivamente levadas em conta não correspondem ao somatório das diferenças 'objetivas'; são apenas aquelas que os próprios atores consideram significativas" (Barth, 2000, p. 33).

No tocante ainda à fala do entrevistado $n^{\circ} 3$, outras pessoas de nacionalidade paraguaia não chancelam sua opinião. "Eu acho que vocês [Brasil] têm que atender todo mundo, sim. O país de vocês é rico, o nosso é pobre. E muito da nossa pobreza é culpa dos brasileiros." O contexto em que deu essa declaração foi bastante peculiar na trajetória do trabalho de campo realizado na fronteira de Pedro Juan Caballero e Ponta Porã. A opinião acima foi emitida de forma intempestiva e espontânea, logo após a resposta do entrevistado $n^{\circ} 3$, por uma vendedora ambulante de chipa ${ }^{5}$ que presenciava nossa conversa.

A opinião da vendedora ambulante é partilhada por outros paraguaios quando o tema é o acesso à saúde na fronteira. Muitos deles acreditam que o Brasil tem um débito para com eles, notadamente por conta da participação do país na Guerra da Tríplice Aliança e dos espólios de guerra auferidos quando do pagamento das indenizações.

5 A chipa, alimento tradicional da culinária paraguaia, assemelha-se ao pão de queijo mineiro, todavia com aparência e sabor peculiares. Enquanto o pão de queijo é confeccionado em forma de bolinha, a chipa é modelada em forma de ferradura. Seus ingredientes, geralmente, são: polvilho doce, azeite de oliva ou óleo vegetal, ovos, sal, queijo ralado, margarina e leite (cf. Miró Ibars, 2004). 
A imagem que o paraguaio tem do Brasil é, geralmente, a de uma nação imperialista, dominante e prepotente. Circula entre os paraguaios a noção de que o Brasil se apossou ilegalmente de território a eles pertencente por ocasião do término da guerra de 1870. A esse fato outros se somam, tais como as questões atinentes à ocupação de terras paraguaias por brasileiros, ${ }^{6}$ o que é visto por eles como formas de usurpação, tanto de direitos quanto de dignidade (Albuquerque, 2009).

Quando indagados a respeito da legalidade do atendimento aos estrangeiros, especialmente os que se utilizam da tática de apresentar endereço de outrem como se deles fosse para serem atendidos pelo SUS no Brasil, os discursos dos brasileiros denotam uma solidariedade que extrapola as fronteiras físicas

Pode até ser ilegal, sabe. Mas não por isso que não vai atender, né? Vai deixar a pessoa morrer ou sofrer à toa, sem precisão, num vai, né? Imagina se fosse um parente da gente, Deus me livre! E o Brasil é todo errado mesmo, então um erro a mais um a menos, num faz diferença. Nós [os brasileiros] não somos exemplo pra ninguém, começa lá de cima a cachorrada, a roubalheira. Eu mesmo já emprestei meu endereço pra um amigo meu que mora em Pedro Juan. (Entrevistado $n^{\circ} 2$, brasileiro, porteiro, entrevista realizada em Ponta Porã).

Contudo, as opiniões não são unânimes, existindo aqueles que são contrários ao atendimento de estrangeiros pelo Sistema Único de Saúde brasileiro.

O problema é maior do que a gente pensa. A saúde no Brasil não dá conta de atender bem nem aos brasileiros, quanto mais aos estrangeiros, sejam eles paraguaios, bolivianos, venezuelanos ou de qualquer outra nacionalidade. Vivemos um caos na saúde pública no Brasil, basta ligar a TV ou abrir um jornal impresso ou eletrônico que você pode ver isso. Então como é que nós [Brasil] podemos nos responsabilizar pela saúde dos outros, não tem condições. (Entrevistado $n^{\circ} 4$, brasileiro, jornalista, entrevista realizada em Ponta Porã).

A pluralidade de opiniões a respeito do tema é enorme, dividindo os pontaporanenses e os pedrojuaninos em lados antagônicos. No entanto, tal antagonismo

6 Essa migração se intensificou a partir da década de 1950, quando os brasileiros compraram extensas áreas de terra fértil no leste paraguaio para a exploração cafeeira. Sobre o tema, ver Fabrini (2012). 
é compreensível diante da multifacetada e complexa realidade sociocultural da fronteira Brasil/Paraguai, especificamente no caso de Pedro Juan Caballero e Ponta Porã, cidades conurbadas e intrinsecamente interdependentes, onde as relações são nuançadas por fatores de toda sorte e matizes, e em que a dinâmica dos fenômenos que ali ocorrem nem sempre é facilmente perceptível.

Todavia, tais características são comuns em espaços de fronteira, dado sua natureza porosa e intercambiante, mas não isenta de obstáculos, de amálgamas e cisões, de associações e divergências, e de controle e sujeição. Representam, desse modo, espacialidades de exercício de poder, de diversos conflitos e de diversificadas maneiras de expressão de integração cultural (Albuquerque, 2010).

Parte das táticas de acesso aos serviços do SUS na fronteira de Pedro Juan Caballero e Ponta Porã, no tocante aos paraguaios indocumentados, expressada também pelas redes de solidariedade existentes entre brasileiros e paraguaios, é a que conta com a colaboração de funcionários dos hospitais locais, tais como enfermeiros, motoristas, médicos, vigilantes, zeladores e demais atendentes. Aqui, os laços de companheirismo, amizade e reciprocidade ${ }^{7}$ se refletem nas táticas empregadas para acessar os serviços de saúde na região.

Nesse sentido, é comum um desses funcionários interceder por um amigo ou parente de nacionalidade paraguaia: um cunhado ou cunhada que reside em localidade afastada da fronteira, uma prima ou primo paraguaio da esposa, dentre outras relações de parentesco. "Eu cansei de intermediar atendimento aqui para pessoas que vêm do Paraguai" (Entrevistado $n^{\circ} 5$, brasileiro, servidor público, entrevista realizada em Ponta Porã).

Indagados de como seria o procedimento, a tática de ação que possibilita o atendimento, alguns interlocutores responderam que

é simples, sabe? A gente fala com o médico que tá atendendo naquele dia, mas tem que ser um cara da nossa confiança, um médico que a gente tenha feito amizade, né? Senão não dá certo, não dá pra pedir isso pra qualquer um. Daí ele atende a pessoa, passa os remédios, pede exames; faz o que dá pra fazer, senão for

7 Reciprocidade, tema caro à antropologia desde a publicação do Ensaio sobre a dádiva de autoria do antropólogo francês Marcel Mauss (2003), pode ser simplificada pelas expressões populares em que as locuções substantivas toma lá dá cá, uma mão lava a outra e troca de favores traduzem as relações sociais nas quais o princípio da reciprocidade é o mote. 
coisa muito séria. Aqui todo mundo se ajuda nisso. (Entrevistado $n^{\circ} 5$, brasileiro, servidor público, entrevista realizada na cidade de Ponta Porã].

Essas redes parecem extrapolar as concepções de cidadania e nacionalidade intrinsecamente associadas às características atinentes à fronteira física, comunicada nos modos e nos expedientes utilizados por alguns moradores das localidades fronteiriças para facultar a inserção no sistema de saúde. Isso tende a demonstrar uma espécie de desenvolvimento teórico-conceitual do direito de cidadania, denotando a construção de um conceito peculiar da faixa de fronteira, compreendendo-a mais como uma área de passagem do que um espaço de limite territorial (Preuss, 2011).

Ainda no tocante às redes de solidariedade que têm lugar na faixa de fronteira de Pedro Juan Caballero e Ponta Porã, especificamente no que respeita à busca de atendimento de saúde no Brasil, por meio do SUS, é relevante aduzir que não são somente aqueles socioeconomicamente fragilizados que acorrem às táticas para conseguir acesso aos serviços. Segundo alguns interlocutores, paraguaios de melhor condição econômica também procuram usufruir da gratuidade do sistema de saúde brasileiro.

No entanto, para esses, as táticas que favorecem o acesso - quando não estão inseridos nas redes de solidariedade - não são as mesmas adotadas pelas classes menos favorecidas; por vezes, eles têm de oferecer alguma compensação monetária aos funcionários para obter atendimento. Como têm condições financeiras, geralmente pagam ao funcionário que faculta $o$ atendimento metade do valor de uma consulta particular cobrada no Brasil ou em clínicas de saúde de Pedro Juan Caballero.

Todavia, por conta da reciprocidade existente no sistema de táticas empregado pelos funcionários dos estabelecimentos de saúde pública de Ponta Porã, às vezes se providencia um ou outro atendimento a pessoas que flagrantemente, segundo os interlocutores, poderiam pagar por atendimento em hospitais ou clínicas particulares.

Eu não acho certo! Porque eu acho que o SUS é para quem não tem condições de pagar mesmo, não para quem tem dinheiro, seja ele brasileiro ou paraguaio. Mas eu faço quando é pra pagar um favor para alguém aqui. Mas é que aqui funciona o esquema de uma mão lava a outra, entende? Então, às vezes um médico ou 
enfermeiro, a quem a gente deve um favor do mesmo tipo, pede pra gente fazer o mesmo esquema que faz com os estrangeiros sem documento brasileiro. Então, mesmo a gente vendo que a pessoa tem condições, a gente dá um jeito, não por ela [a pessoa], mas pra pagar o favor recebido em outra ocasião. Você entendeu? É assim que funciona. (Entrevistado $n^{\circ} 6$, brasileiro, servidor público, entrevista realizada em Ponta Porã).

Outra maneira que possibilita o atendimento aos estrangeiros no Brasil, como já mencionado, é deixar que o quadro de saúde do enfermo se agrave até à iminência do risco de morte, dado que omissão de socorro constitui crime ${ }^{8}$ no ordenamento jurídico brasileiro. A partir daí, o atendimento pode ser solicitado diretamente no hospital. Em havendo recusa por parte dos profissionais, estes incidiriam em falta ética gravíssima, penalizada com a cassação do registro médico (Nogueira; Simionatto; Silva, 2003).

O problema aqui é o desconhecimento por parte do enfermo a respeito da gravidade de sua doença. Assim, a tática de deixar agravar o quadro de saúde não é muito corrente na fronteira de Pedro Juan Caballero e Ponta Porã, especificamente quando não se conhece o diagnóstico ou este é ainda incerto.

É perigoso, né? Eu mesmo conheço gente que perdeu parente esperando ele ficar um pouquinho pior pra trazer aqui pro médico. Pensou que era uma gastrite, uma úlcera, mas era câncer. Daí, quando trouxeram ele, já muito ruim, era tarde, já tinha espalhado tudo. Então, é muito arriscado, sabe? Mas se for caso conhecido, que a pessoa já trata há algum tempo, daí dá. Ou quando a mulher tá grávida, né? E quer ter o filho aqui no Brasil, pra aproveitar as coisas daqui [o acesso aos serviços], aí dá certo, o risco é pouco. (Entrevistado $n^{\circ} 7$, paraguaio, casillero em Pedro Juan Caballero, entrevista realizada em Ponta Porã).

8 “Omissão de Socorro Art. 135. Deixar de prestar assistência, quando possível fazê-lo sem risco pessoal, à criança abandonada ou extraviada, ou à pessoa inválida ou ferida, ao desamparo ou em grave e iminente perigo; ou não pedir, nesses casos, o socorro da autoridade pública: Pena detenção, de um a seis meses, ou multa. Parágrafo único - A pena é aumentada de metade, se da omissão resulta lesão corporal de natureza grave, e triplicada, se resulta a morte" (cf. Greco, 2016, p. 581, grifo do autor). 
A propósito do parágrafo acima, cabe menção à tática adotada pelas parturientes paraguaias quando querem que seus filhos tenham cidadania brasileira, podendo, assim, desfrutar dos direitos inerentes a essa condição.

A gestante do Paraguai, o que ela faz, isso se aprende, eles aprendem entre eles. Ela vai a nossa unidade hospitalar e o hospital fala para ela, olha você é do Paraguai, a senhora pode ir para casa e ter seu filho no Paraguai. Então o que elas aprenderam. Que se tiver em um período mais próximo do trabalho de parto ninguém vai mandá-las embora, é emergência, então elas ficam, aguentam o quanto podem [...] a dor do trabalho de parto e chegam ao hospital numa situação que não dar mais para excluí-las, tem que atender [...]. O parto é de graça, o filho é brasileiro, tem toda a assistência, elas podem pedir naturalização, ou visto de permanência, então isso onera para nós. Muitas não têm pré-natal, às vezes tem doenças bem complicadas, sempre acabam alterando o sossego [...] (Brasil, 2007 apud Albuquerque, 2012, p. 198).

Algumas pesquisas trazem à baila problemas relacionados às táticas de inserção no sistema de saúde do Brasil, adotadas pelos não nacionais do país. Ocorrências que envolvem litígios judiciais que têm como protagonistas os bebês que quando nascem são registrados não nos nomes dos pais biológicos, mas nos nomes daquelas pessoas que emprestaram o número de Cadastro de Pessoa Física (CPF) a um indivíduo de origem estrangeira para fins comprobatórios de residência no território nacional (Nogueira; Silva, 2009). No entanto, isso só ocorre com aquela parcela menos informada a respeito do funcionamento do ordenamento jurídico brasileiro no que diz respeito aos direitos dos estrangei$\operatorname{ros}^{9}$ quando em território nacional.

Diante do exposto, fica claro o intrincado universo sociocultural que a fronteira delineia, deixando a descoberto as inúmeras dificuldades existentes no que diz respeito à apreensão e interpretação dos fenômenos ensejados pela dinâmica peculiar desses espaços.

9 Lei n ${ }^{\circ}$ 6.815/1980: "O estrangeiro residente no Brasil goza de todos os direitos reconhecidos aos brasileiros, nos termos da Constituição e das leis” (Brasil, 1980, art. 95). Esta lei também é conhecida no Brasil como Estatuto do Estrangeiro. 


\section{Conclusão}

O acesso aos serviços de saúde por parte dos estrangeiros, especificamente os paraguaios, constitui um problema grave às autoridades brasileiras, notadamente aquelas responsáveis pelo aporte de recursos destinados aos municípios fronteiriços - já que sabidamente os atendimentos realizados aos estrangeiros indocumentados e aos brasileiros residentes no Paraguai não entram no cômputo geral quando da alocação de recursos financeiros.

Entretanto o problema de acesso à saúde na fronteira Brasil/Paraguai não é somente do Estado brasileiro, mas também dos estrangeiros que nela circulam, dado sua necessidade premente de inclusão em um sistema excludente. Diante dessa necessidade de inclusão nascem as táticas, oportunizadas pelas falhas das estratégias erigidas pelo Estado e operacionalizadas pelas redes de solidariedade - estas tributárias de tantas outras redes, engendradas e lapidadas no devir da vida cotidiana do morador da fronteira.

Assim, os atendimentos que têm as táticas como meio de operacionalização são realizados, à revelia do controle do Estado brasileiro. Para viabilizar o acesso à saúde no Brasil, os paraguaios indocumentados lançam mão dos expedientes aqui aduzidos, arriscando, em alguns casos, a própria vida, dado que a espera pode - como explicitado - concorrer com o agravamento da doença para além das possibilidades de cura.

As táticas de acesso acionadas pelos estrangeiros demonstram a fragilidade dos mecanismos de controle do Estado brasileiro, deixando a descoberto sua incompetência no tocante à solução dos problemas enfrentados nas fronteiras do país, especificamente os que têm a saúde como foco. Nesse sentido, enquanto o Estado brasileiro procura dificultar o acesso aos serviços de saúde por parte dos estrangeiros, impossibilitando-lhes a inclusão adotando estratégias excludentes, estes se valem dos arranjos mais inusitados para serem atendidos, contando com a conivência e/ou cumplicidade dos brasileiros moradores na região de fronteira.

Tal conivência e cumplicidade podem ser explicadas por meio da análise minuciosa das inúmeras inter-relações socioculturais que a condição de fronteira oportuniza. Para além dos marcos regulatórios e dos mapas que delimitam os territórios, impera a realidade cotidiana dos fronteiriços, matizada não somente pelas relações comerciais, tanto legais quanto ilegais, do ponto de 
vista do ordenamento jurídico dos Estados, mas também pela empatia, pela camaradagem, pela amizade e por tantas outras relações socioafetivas que, independentes da nacionalidade, plasmam o tecido sociocultural em que viceja o gênero humano.

Salta aos olhos a inexistência, ou existência fantasiosa, de efetivas políticas públicas de inclusão elaboradas para solucionar os problemas relacionados ao acesso à saúde aos estrangeiros nas fronteiras do Brasil. São muitas as pesquisas realizadas sobre o tema, apontando os principais gargalos e as soluções possíveis. Mas o Estado brasileiro finge não conhecê-las, ou quando as conhece alega impossibilidade financeira para viabilizar a resolução dos entraves e, com isso, franquear o acesso.

\section{Referências}

AGUSTINI, J. A descentralização da política nacional de saúde e sua institucionalidade nos sistemas municipais na linha da fronteira Mercosul. 2008. Dissertação (Mestrado em Serviço Social)-Centro Sócio-Econômico, Universidade Federal de Santa Catarina, Florianópolis, 2008.

ALBUQUERQUE, J. C. L. A dinâmica das fronteiras: deslocamento e circulação dos "brasiguaios" entre os limites nacionais. Horizontes Antropológicos, Porto Alegre, ano 15, n. 31, p. 137-166, jan.jjun. 2009.

ALBUQUERQUE, J. C. L. Conflito e integração nas fronteiras dos "brasiguaios". Caderno CRH, Salvador, v. 23, n. 60, p. 579-590, set./dez. 2010.

ALBUQUERQUE, J. C. L. Limites e paradoxos da cidadania no território fronteiriço: o atendimento dos brasiguaios no sistema público de saúde em Foz do Iguaçu (Brasil). Geopolítica(s), Madrid, v. 3, n. 2, p. 185-205, 2012.

ALBUQUERQUE, J. C. L. Migração, circulação e cidadania em território fronteiriço: os brasiguaios na fronteira entre o Paraguai e o Brasil. Tomo, São Cristóvão, n. 26, p. 98-122, jan./jun. 2015.

ALVAREZ, G. O. Identidades migrantes, fronteira e cidadania. In: SOARES, M.; MATTOS, I. M.; MARTINS, D. C. (Org.). Região e poder, representações em fluxo. Goiânia: Editora da PUC Goiás, 2010. p. 65-88.

ALVAREZ JÚNIOR, R. R. The mexican-US border: the making of an anthropology of borderlands. Annual Review of Anthropology, Palo Alto, v. 24, p. 447-470, 1995. 
AZEVEDO, S. T. de. As percepções sobre a saúde na fronteira Brasil e Paraguai: os transfronteriços e o atendimento pelo SUS. In: ENCONTRO NACIONAL DA ANPEGE, 11., 2015, Presidente Prudente. Anais..., Presidente Prudente: Anpege, 2015. p. 55465556. Disponível em: <http://www.enanpege.ggf.br/2015/anais/arquivos/18/518.pdf>. Acesso em: 5 ago. 2017.

BANDUCCI JÚNIOR, A. Turismo e fronteira: integração cultural e tensões identitárias na divisa do Brasil com o Paraguai. Pasos, El Sauzal, v. 9, n. 3, p. 7-18, 2011.

BARTH, F. O guru, o iniciador e as outras variações antropológicas. Rio de Janeiro: Contra Capa, 2000.

BRASIL. Código Penal. Decreto-Lei n 2.848, de 7 de dezembro de 1940. Diário Oficial [da] República Federativa do Brasil, Brasília, 31 dez. 1940, n. 302, Seção 1, p. 23911.

BRASIL. Lei n 6.815, de 19 de agosto de 1980. Diário Oficial [da] República Federativa do Brasil, Brasília, 21 ago. 1980. Seção 1, p. 16533.

BRASIL. Portaria $\mathrm{n}^{\circ}$ 1.560, de 29 de agosto de 2002. Diário Oficial [da] República Federativa do Brasil, Brasília, 30 ago. 2002, n. 168, Seção 1, p. 84-85.

BRASIL. Ministério da Saúde. Sistema Integrado de Saúde das Fronteiras: SIS Fronteiras e a integração em busca da equidade. Brasília, 2005.

BRASIL. Lei $n^{\circ} 4.082$ de 06 de setembro de 2011. Diário Oficial [da] República Federativa do Brasil, Brasília, 8 set. 2011, n. 8027, p. 1.

BRASIL. Ministério da Integração Nacional. Portaria nº 125, de 21 de março de 2014. Diário Oficial [da] União, Brasília, 24 mar. 2014, n. 56, Seção 1, p. 45. Disponível em: <http://www.lex.com.br/legis_25369237_PORTARIA_N_125_DE_21_DE_MARCO_D>. Acesso em: 5 ago. 2017.

BRASIL. Ministério da Saúde. Cadastro Nacional de Estabelecimentos de Saúde - Ponta Porã (MS). Brasília, 2016. Disponível em: <http://cnes2.datasus.gov.br/Mod_Ind_Unidade.asp?VEstado=50\&VMun=\&VComp=201406> . Acesso em: 5 ago. 2017.

CERTEAU, M. de. A invenção do cotidiano: artes de fazer. Petrópolis: Vozes, 1994.

DIRECCIÓN GENERAL DE ESTADÍSTICA, ENCUESTAS Y CENSOS. Resultados finales del Censo 2002. Asunción, 2002. Disponível em: <http://www.dgeec.gov.py/>. Acesso em: 5 ago. 2017.

FABRINI, J. E. Conflitos de terra na fronteira Brasil-Paraguai e luta dos brasiguaios. Uberlândia: ENGA-UFU, 2012.

GADELHA, C. A. G.; COSTA, L. Integração de fronteiras: a saúde no contexto de uma política nacional de desenvolvimento. Cadernos de Saúde Pública, Rio de Janeiro, v. 23, supl. 2, p. 214-226, 2007. 
GARCÍA CANCLINI, N. Culturas híbridas. São Paulo: Edusp, 1997.

GIOVANELLA, L. et al. Saúde nas fronteiras: acesso e demandas de estrangeiros e brasileiros não residentes ao SUS nas cidades de fronteira com países do MERCOSUL na perspectiva dos secretários municipais de saúde. Cadernos de Saúde Pública, Rio de Janeiro, v. 23, n. 2, p. 251-266, 2007.

GOETTERT, J. D. Fronteiras na fronteira: falas atravessadas entre Brasil e Paraguai. Revista Geonorte, Manaus, v. 7, n. 1, p. 748-766, 2013.

GRECO, R. Código penal comentado. Niterói: Ímpetos, 2016.

GRIMSON, A. La nación en sus límites: contrabandistas y exilados em la frontera Argentina-Brasil. Barcelona: Gedisa, 2003.

IPC MARKETING. IPC Target 2010. São Paulo, 2010. Disponível em: <http://www.ipcmarketing.com.br/downpress/Ranking_IPC_2010_2009_500Maiores.pdf>. Acesso em: 10 dez. 2013.

INSTITUTO BRASILEIRO DE GEOGRAFIA E ESTATÍSTICA. Cidades: Ponta Porã/MS. 2011. Disponível em: <https://cidades.ibge.gov.br/xtras/perfil.php?lang=\&codmun=5 00660\&search=mato-grosso-do-sul|ponta-pora>. Acesso em: 5 ago. 2017.

LEACH, E. R. Sistemas políticos da Alta Birmânia. São Paulo: Edusp, 1996.

MARTINS, P. C. S.; BANDUCCI JÚNIOR, A. Turismo de compras no território fronteiriço de Pedro Juan Caballero/PY: breves considerações. 2009. Disponível em: <http://paraguay. sociales.uba.ar/files/2011/08/P_martins_banducci_2009.pdf>. Acesso em: 5 ago. 2017.

MAUSS, M. O Ensaio sobre a dádiva. In: MAUSS, M. Sociologia e antropologia. São Paulo: Cosac Naify, 2003. p. 183-294.

MIRÓ IBARS, M. Karú reko: antropología culinaria paraguaya. Asunción: Servilibro, 2004.

NASCIMENTO, V. A. "Yo soy paraguayo, chamigo": breve estudo sobre a identidade no Paraguai. 2012. Dissertação (Mestrado em Antropologia)-Faculdade de Ciências Humanas, Universidade Federal da Grande Dourados, Dourados, 2012.

NASCIMENTO, V. A. Fronteiriço, brasileiro, paraguaio ou brasiguaio? Denominações identitárias na fronteira Pedro Juan Caballero (PY) e Ponta Porã (BR). Ilha: Revista de Antropologia, Florianópolis, v. 16, n. 1, p. 105-137, jan./jul. 2014.

NOGUEIRA, V. M. R.; FAGUNDES, H. S. A implementação do SIS Fronteiras - Perspectivas para a ampliação do direito à saúde na fronteira arco sul. Serviço Social e Saúde, Campinas, v. 13, n. 2, p. 245-260, jul./dez. 2014. Disponível em: <https://periodicos.sbu.unicamp.br/ojs/index.php/sss/article/view/8634903/2801>. Acesso em: 5 ago. 2017. 
NOGUEIRA, V. M. R.; GIMÉNEZ, R. P. A política nacional de saúde para as regiões fronteiriças - inovações e limites. 2010. Trabalho apresentado. XIII Congresso Brasileiro de Assistentes Sociais, Brasília, 2010. Disponível em: <http://docplayer.com. br/12381075-Palavras-chave-sis-fronteiras-pactos-pela-saude-fronteiras-sistemas-municipais-de-saude.html>. Acesso em: 5 ago. 2017.

NOGUEIRA, V. M. R.; SILVA, M. G. da. Brasiguaios: a cidadania fluída na tríplice fronteira. 2007. Trabalho apresentado. III: Jornada Internacional de Políticas Públicas, São Luís, 2007. Disponível em: <http://www.joinpp.ufma.br/jornadas/joinppIII/ html/Trabalhos/EixoTematicoJ/8fb4146dae9fce4fd92bVera_Geusina.pdf > Acesso em: 5 ago. 2017.

NOGUEIRA, V. M. R.; SILVA, M. G. da. Direito, fronteiras e desigualdade em saúde. Revista em Pauta, Rio de Janeiro, v. 6, n. 24, p. 83-98, dez. 2009.

NOGUEIRA, V. M. R.; SIMIONATTO, I.; SILVA, M. G. Fronteira Mercosul processo de inclusão e exclusão no Sistema Único de Saúde brasileiro. Serviço Social em Revista, Londrina, v. 6, n. 1, p. 1-24, jul./dez. 2003.

NOGUEIRA, V. M. R. et al. Políticas de saúde nos países do Mercosul: um retorno à universalidade?. Revista de Políticas Públicas, São Luís, v. 19, n. 1, p. 145-156, jan./jun. 2015.

PARAGUAY. Ministerio de la Salud Pública y Bienestar Social. Lista de establecimientos sanitarios. 2016. Disponível em: <https://www.datos.gov.py/dataset/lista-de-establecimientos>. Acesso em: 5 ago. 2017.

PEITER, P. C. A geografia da saúde na faixa de fronteira continental do Brasil na passagem do milênio. 2005. Tese (Doutorado em Geografia)-Instituto de Geociências, Universidade Federal do Rio de Janeiro, Rio de Janeiro, 2005.

PEREIRA, M. G. Epidemiologia: teoria e prática. Rio de Janeiro: Guanabara Koogan, 2000.

PINHEIRO-MACHADO, R. Made in China: produção e circulação de mercadorias no circuito China-Paraguai-Brasil. 2009. Tese (Doutorado em Antropologia Social)-Instituto de Filosofia e Ciências Humanas, Universidade Federal do Rio Grande do Sul, Porto Alegre, 2009.

PREUSS, L. T. O direito à saúde na fronteira: duas versões sobre o mesmo tema. 2007. Dissertação (Mestrado em Serviço Social)-Centro Sócio-Econômico, Universidade Federal de Santa Catarina, Florianópolis, 2007.

PREUSS, L. T. O direito à saúde na fronteira: duas versões sobre o mesmo tema. 2011. Trabalho apresentado. Diprosul, Pelotas, 2011.

SCOTT, J. C. Weapons of the weak: everyday forms of peasant resistance. New Haven: Yale University Press, 1985. 
SILVA, M. G. da. O local e o global na atenção às necessidades de saúde dos brasiguaios: análise da intervenção profissional do assistente social em Foz do Iguaçu. 2006. Dissertação (Mestrado em Serviço Social)-Centro Sócio-Econômico, Universidade Federal de Santa Catarina, Florianópolis, 2006.

SPRANDEL, M. A. Brasileiros na fronteira com o Paraguai. Estudos Avançados, São Paulo, v. 20, n. 57, p. 137-156, ago. 2006. Disponível em: <http://www.scielo.br/pdf/ea/ v20n57/allv2057.pdf>. Acesso em: 5 ago. 2017.

TAMAKI, E. M. et al. O projeto SIS-Fronteira no Estado de Mato Grosso do Sul. In: SOUZA, M. L. et al. (Org.). A saúde e a inclusão social nas fronteiras. Florianópolis: Boiteux, 2008. p. 177-208.

TRAVASSOS, C.; MARTINS, M. Uma revisão sobre os conceitos de acesso e utilização de serviços de saúde. Cadernos de Saúde Pública, Rio de Janeiro, v. 20, n. 2, p. 144-145, 2004.

VIEGAS, S. M. da F.; PENNA, C. M. de M. O SUS é universal, mas vivemos de cotas. Ciência e Saúde Coletiva, Rio de Janeiro, v. 18, n. 1, p. 181-190, 2013. 